\title{
PATENTS IN THE TWITTER PRODUCT SIDE
}

\author{
Putra Rahmadi \\ 155100058 \\ Fakultas Komputer, 4487571-67 \\ putrarahmadi.student@umitra.ac.id
}

\begin{abstract}
Twitter has gained popularity throughout the world and currently has more than 100 million users. This is sometimes described as "SMS from the internet". Twitter has a patent logo right in the form of a blue bird named "Larry the" Bird ", named after the name of a former NBA basketball player, Larry Bird.
\end{abstract}

Keywords: patents on the twitter logo

\section{A. INTRODUCTION}

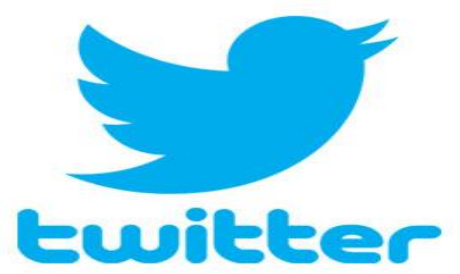

witter is a website that is owned and operated by Twitter Inc., which offers social networking in the form of microblogs, allowing users to send and read messages called tweets. Twitter is a text of up to 140 characters displayed on the user's profile page. Twitter can be seen outside, but the sender can restrict sending messages to their list of friends only. Users can see the tweets of other authors known as followers ("followers").
Twitter itself began with a discussion organized by the board member of the Odeo Podcasting company. During the meeting, Jack Dorsey introduced the idea of twitter where individuals could use SMS services to communicate with a small group. This project began on the 21st open on July 15, 2006. Twitter became its own company in April 2007.

Twitter's popularity began to increase in 2007 when there was the South by Southwest (SXSW) festival. During the event, Twitter usage increased from 20,000 tweets per day to 60,000 . The reaction at the festival was very positive. 
On September 14, 2010, Twitter changed the logo and launched a new design and the logo changed again to "Larry the" Bird "on June 5, 2012. The logo was directly patented so that no one from another company copied or copied the blue bird's logo.

\section{B. CONCLUSION}

Witter is a website operated by Twitter Inc., Twitter was first podcasted by Odeo company. And now Twitter has left the Odeo company and now Twitter has its own company. Twitter is defined as Twitter, Twitter is interpreted as writing text up to 140 characters displayed on the user's profile page. And Twitter changed its logo to a blue bird which was patented right to become its Twitter logo

\section{ACKNOWLEDGEMENT}

University Of Indonesia

University Of Mitra Indonesia

Telkom University

University Of Mellbourne

Saitama University 
Jaringan Komputer." (2018).

[5] Putra, A. S. (2018, July 17). Paperplain Fundamental Create Application With Borland Delphi 7.0 University Of Mitra Indonesia. Retrieved From Osf.Io/Pbrn9.

\section{REFERENCE(Based ISO 690 )}

[1]

\begin{abstract}
A. S. Putra And O. M. Febriani, "Knowledge Management Online Application In Pdam Lampung Province," In Prosiding International Conference On Information Technology And Business (Icitb), 2018, Pp. 181-187.
\end{abstract}

[2] A. S. Putra, O. M. Febriani, And B. Bachry, "Implementasi Genetic Fuzzy System Untuk Mengidentifikasi Hasil Curian Kendaraan Bermotor Di Polda Lampung," J. Sist. Inf. Dan Manaj. Basis Data, Vol. 1, No. 1, Pp. 21-30, 2018.

[3] O. M. Febriani And A. S. Putra, "Sistem Informasi Monitoring Inventori Barang Pada Balai Riset Standardisasi Industri Bandar Lampung," J. Inform., Vol. 13, No. 1, Pp. 90-98, 2014.

[4] Putra, Arie Setya. "2018 Artikel Struktur Data, Audit Dan

\section{E. REFERENCE(Based APA )}

Putra, A. S., Aryanti, D. R., \& Hartati, I. (2018, November). Metode SAW (Simple Additive Weighting) sebagai Sistem Pendukung Keputusan Guru Berprestasi (Studi Kasus: SMK Global Surya). In Prosiding Seminar Nasional Darmajaya (Vol. 1, No. 1, pp. 85-97).

Sari, D. P., Febriani, O. M., \& Putra, A. S. (2018, November). Perancangan Sistem Informasi SDM Berprestasi pada SD Global Surya. In Prosiding Seminar Nasional Darmajaya (Vol. 1, No. 1, pp. 289-294).

Putra, A. S. (2018). Paperplain: Execution Fundamental Create Application With Borland Delphi 7.0 University Of Mitra Indonesia.

Putra, A. S., Sukri, H., \& Zuhri, K. Sistem Monitoring Realtime Jaringan Irigasi Desa (JIDES) Dengan Konsep Jaringan Sensor Nirkabel. IJEIS (Indonesian Journal of Electronics and 
Instrumentation Systems), 8(2), 221232.

Darmawan, A., Yuliawati, D., Marcella, O., \& Firmandala, R. (2016). Sistem Absensi dan Pelaporan Berbasis Fingerprint dan SMS Gateway. EXPLORE, 7(1).

Febriani, O. M., Wahyuni, T., \& Yusuf, S. (2017). DESIGN OF WEBSITE-BASED INFORMATION SYSTEM FOR EDOCUMENT ADMINISTRASI IN THE COMMUNITY SERVICE UNIT (A Case Study at Rajabasa District). INTERNATIONAL JOURNAL OF COMPUTERS \& TECHNOLOGY, 16(7), 7010-7020.

Febriani, O. M., \& Wahyuni, T. (2017, October). PERANCANGAN SISTEM E-DOCUMENT ADMINISTRASI LOGBOOK PENELITIAN PADA UNIT LAYANAN DI BANDAR LAMPUNG. In Prosiding Seminar Nasional Darmajaya (Vol. 1, No. 1, pp. 187-194).

Febriani, O. M., \& Permadi, A. B. (2017). Implementasi Sistem Aplikasi Data Bimbingan dan Pelanggaran Siswa pada Sekolah Menengah Atas di Lampung Tengah dengan Metode Analisis dan Desain Sistem Terdistribusi (SSAD). EXPERT, 7(1).

Febriani, O. M., \& Ambarwati, L. (2015). PERANCANGAN APLIKASI PENGOLAHAN DATA PENJUALAN UKM KELANTING KHAS TELO DESA SIDOHARJO KECAMATAN JATI AGUNG KABUPATEN LAMPUNG
SELATAN. Jurnal Teknologi Informasi dan Bisnis Pengabdian Masyarakat Darmajaya, 1(1), 77-95.

Febriani, O. M. (2015). Rancang Bangun Aplikasi Ecommercemenggunakan Freewebstore pada UKM Kelanting di Desa Sidoharjo Lampung Selatan. Prosiding Sembistek 2014, 1(02), 446-458. 